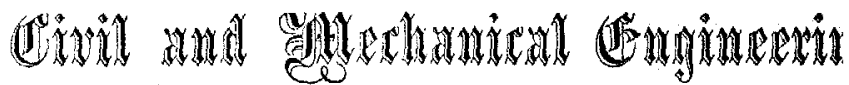

\section{CONCLUDING REPORT OF THE COMMITTEE OF THE FRANKLIN INSTITUTE ON THE MODE OF DETERMINING THE HORSE-POWER OF STEAM-BOILERS.}

\section{INTRODUCTORY.}

In the preliminary report furnished by the Committee in last June, they confined themselves to the definition of the term Horse-power, as applied to steam-boilers, and to the general conditions which should be observed in any trial having for its object the ascertaining of the horse-power developed.

This report was forwarded to and read by a large number of experienced engineers and boiler-makers in the United States and England, who coincided thoroughly with the statement therein expressed, viz., that when the term horse-power is applied to the steam boiler, it signifies the evaporation of a cubic foot of water from and at 212 degrees under the usual conditions of practice, and with an average amount of economy per lb. of combustible common to boilers of that class, which in our previous report was assumed at 9 lbs. for stationary boilers.

They all deprecate the practice of estimating the horse-power of the boiler from the work done by the engine attached.

At the same time it would be perfectly satisfactory for any seller or purchaser of steam-boilers to stipulate for an evaporative capacity of a given number of cubic feet or pounds of water per hour, with an economy of so many pounds of water per pound of combustible.

Either course affords a basis of comparison and a definite amount of power to be supplied, and in justice to the public one or the other mode should be adopted, or the term horse-power abandoned in the sale of boilers.

It was the intention of the Committee, before concluding their report, to furnish some data concerning the number of square feet of heating-surface required per horse-power on various types of boilers. In order to obtain these, they forwarded their preliminary report to many engineers and engine-builders in large practice. The replies received indicate that very little has been done with that end in view,

Vol. LXIV.-Third Serins.-No. 2.-A AGUst, 1872. 
and consequently the results obtained are defective from the omission of some important data in the trial. Mr. R. B. Longridge, of Manchester, England, who has had a large experience in this line, says, under date of October 9th, 1871, that "no experiments have ever been made in this country sufficiently complete to enable any one to solve the question submitted to the Committee."

Since the above was written, we have the pleasure of reporting that the Managers of the Fair of the American Institute, New York, have tested four boilers submitted for competitive examination, in the most thorough and scientific manner. We believe this is the only trial on record in which the quality of the steam, or, in other words, the amount of heat transmitted to the water evaporated, was made the subject of investigation. We regard this as but the commencement of a series of experiments which will have as their object the material improvement of boilers, and give them that prominence and proper share in the economic production of power, heretofore given almost exclusively to the steam-engine.

The summary of the report, which we give elsewhere, shows the comparative evapolative efficiency of the said boilers when new and well managed.

Whilst we have been able to collect little that is reliable and conclusive, we do not ignore the vast amount of experiments which have been made incidentally for other objects (such as to establish the economic values of coals, \&c.), and we append hereto some of the results obtained in trials of stationary, marine and portable engine-boilers.

Stationary Boilems.-Report of R. B. Longridge.

We have received from Robert B. Longridge, Chief Engineer of the Manchester (England) Boiler Insurance Company, a pamphlet on the relative economy and durability of stationary steam-boilers. It contains the substance of a paper read before the Institution of Mechanical Engineers, at Leeds, Sept., 1859, and from which we make some interesting extracts.

The cuts following show the type of boiler experimented upon, and the Table IV which follows gives the heating-surface. This is calculated by omitting the under side of internal flues and tubes, as being unavailable. It is important to notice this in comparing the hentingsurface of different boilers, otherwise there may appear a great discrepancy in the heating-surface required. For instance, in the multitubular boilor, under Fig. 14, the heating-surface given as $5.8 \mathrm{sq} . \mathrm{ft}$. 
ECONOMY \&C. OF STEAM BOILERS.

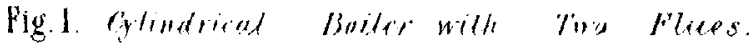

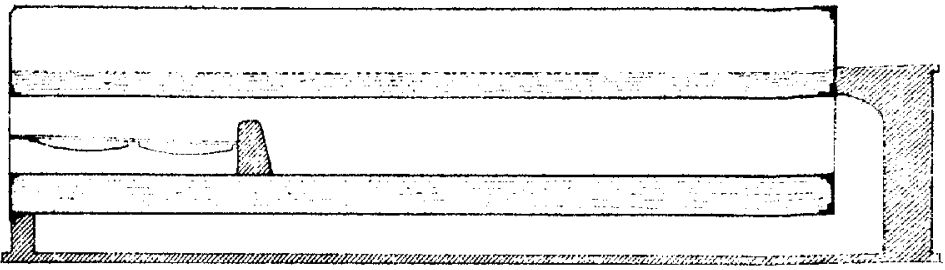

Fig. 3. Gglindrioul Boiler wilh Five Flues.

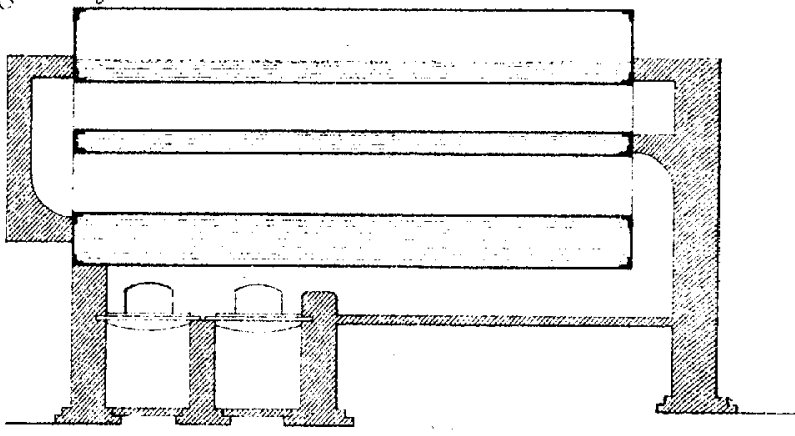

Fig. 5. Multiflued Boider wilh seren Pleces

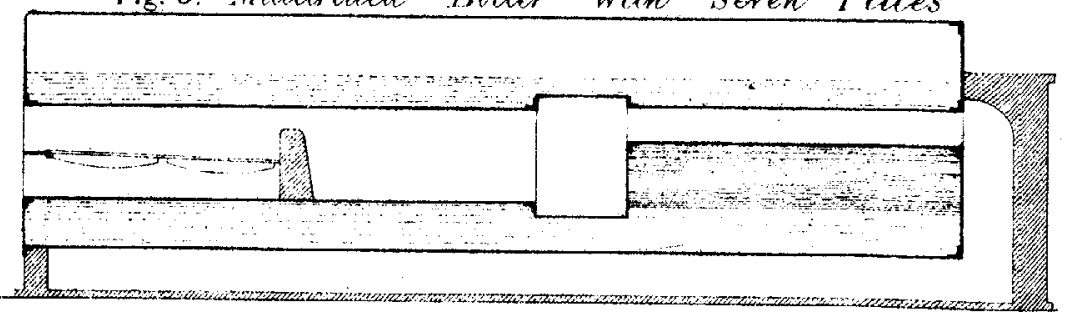

Transterse seclion of Fig. 1

Fig. 2.

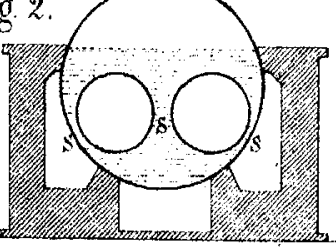

Transverse Fection of Fig.5

Fig. 6.

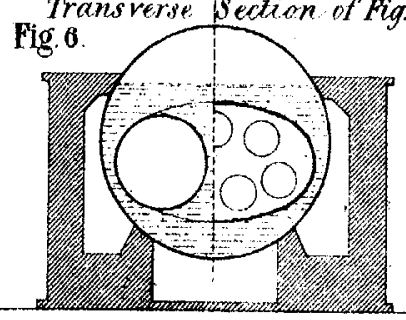

fig. 4.

Transrerse Sextion of Fig. 3

(Proceedings Inst M.E. 1859. Page 247) 
ECONOMY \&C. OF STEAM BOILERS.

Fig. 7 Galloway Boiler:
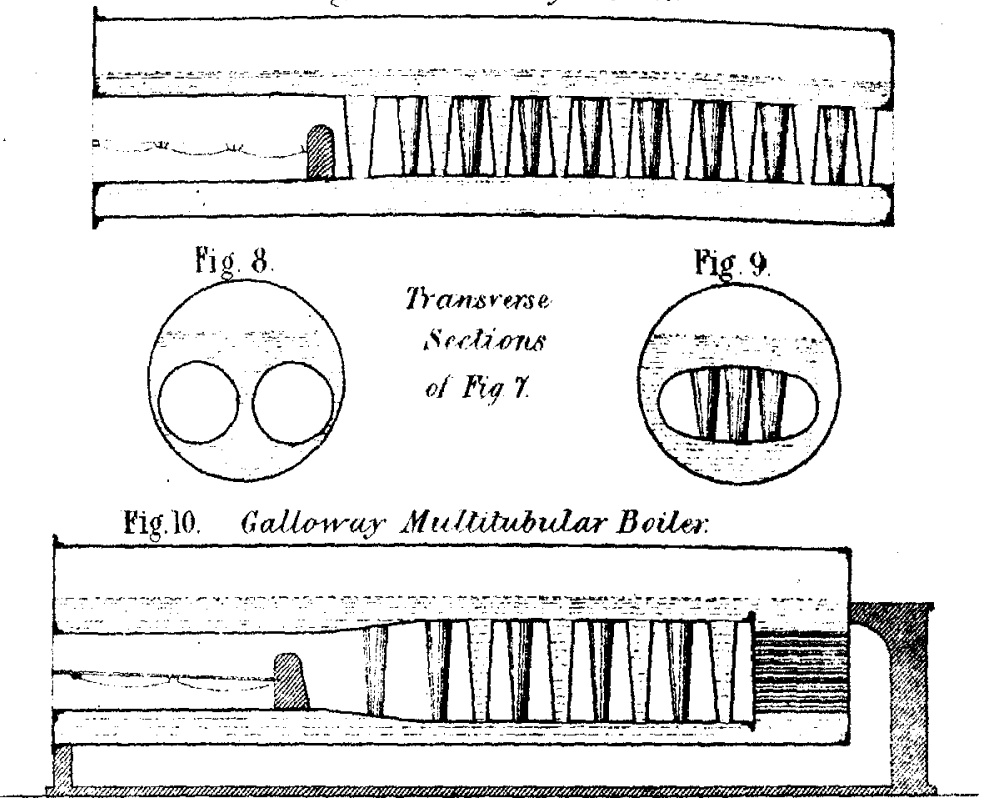

Transwerse Sections of Fig. 10.

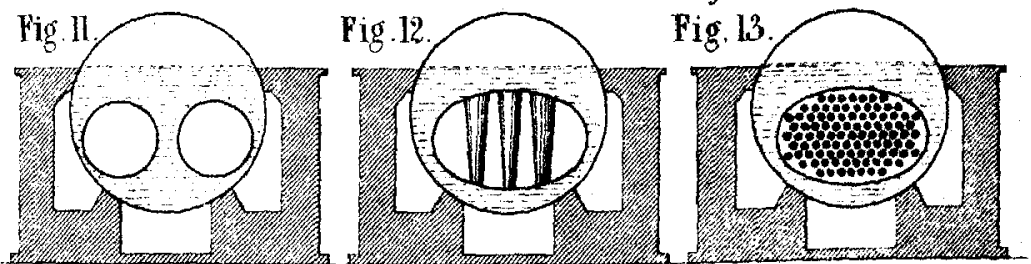

Fig. 14. Multitubular Boiler.

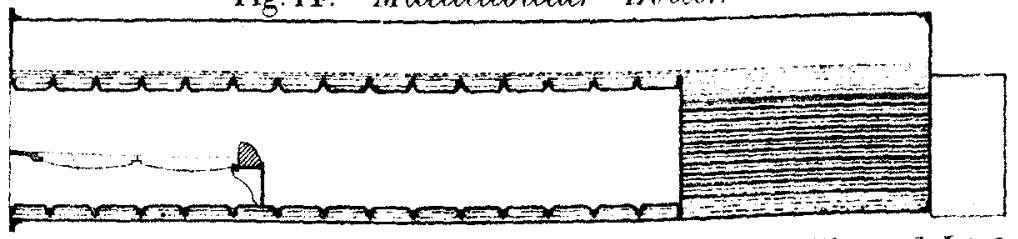

Trenswome Section of Fig. 14. EndElevation of Fig.l4.

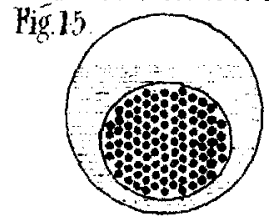

Fig. 10.
Fig. 17. Flanged Joint
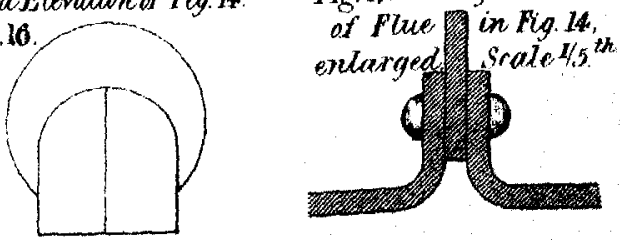

Scale $4 / 100^{\text {th }}$

(Proceedings lnst M.E. 1859. Page.147.)

Mlwoto.incography by F. A. Wenderoth, 933 Arch Street. Philadelphia.

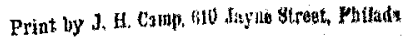




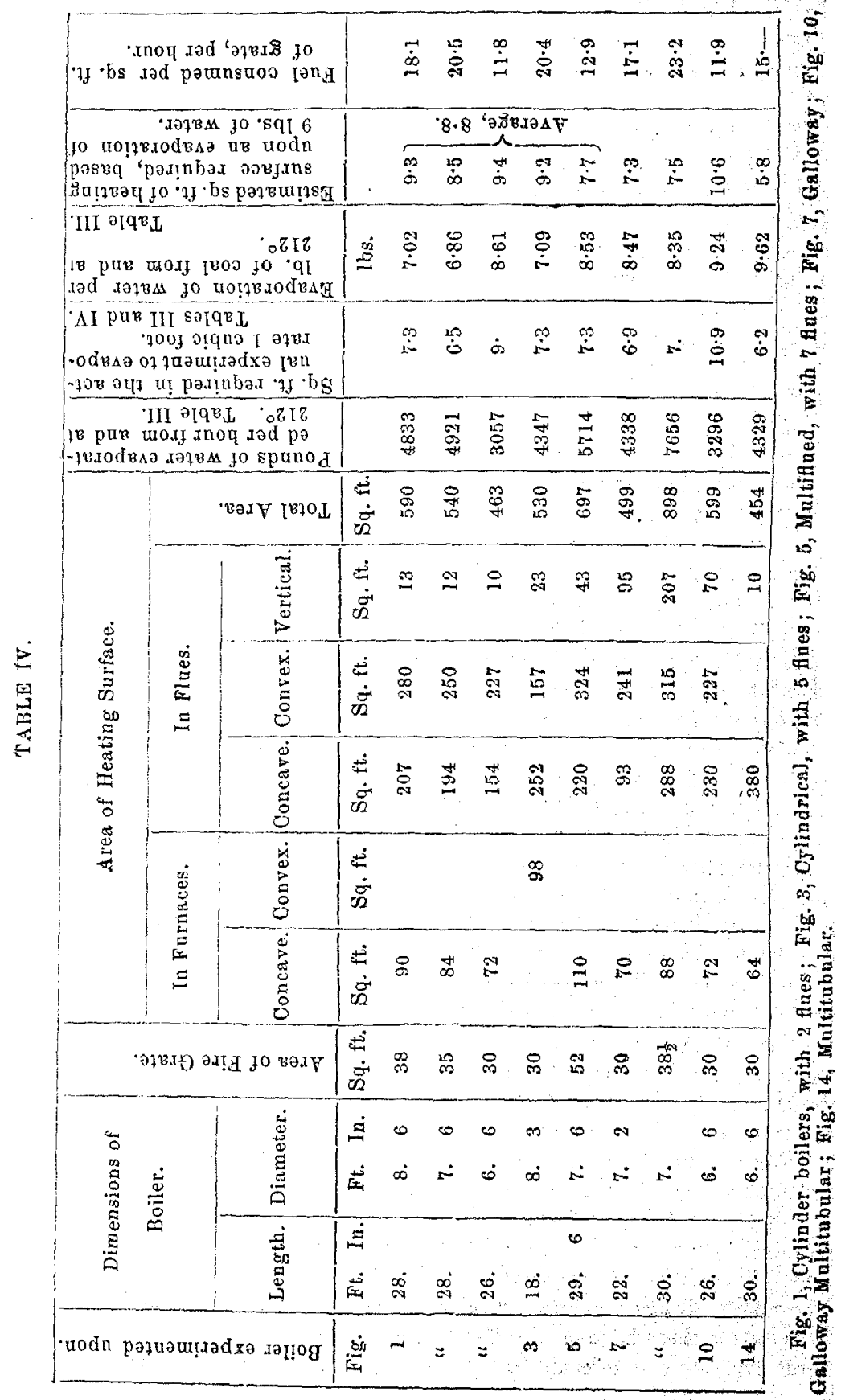


per h.-p., would be over $10 \mathrm{sq}$. feet if all the tube surface had been included.

We make the following extracts from the pamphlet referred to:

In Table IV the several kinds or positions of heating surface are distinguished not only as furnaces and flue surfaces, but also as convex, concave and vertical surfaces; for the value of any surface must depend much upon the position relative to the source of heat, the direction of the gases from the furnace, and the degree of circulation of the water in the boiler, or, in other words, upon the more or less favorable position of the surface for receiving or taking up the heat, and on the facility with which the heat is communicated by means of the circulation of the water. In the internal flues or tubes of boilers, the deposit of dust and ashes from the fuel greatly retards the transmission of heat through the plates. On this account, and from the unfavorable position of the lower balf of cylindrical flues, and also of horizontal surfaces forming the under side of flues or combustion chambers, it has been usual to exclude these in estimating the area of heating surface, as is the case in the areas given in Table IV. From the frequent fracture of plates in these parts, however, in consequence of overheating, it is evident that these surfaces do absorb and accumulate heat in sufficient amount to cause damage to the metal. By proper circulation of water this might be prevented and steam generated, though possibly not to any practically useful extent. Upper horizontal surfaces, such as the crowns of square fireboxcs and combustion chambers, have hitherto been generally con. sidered the most effective.

This seems, however, to be exceedingly questionable, particularly with regard to horizontal surfaces of large extent; for a surface can only be relatively effective in proportion to the rapidity with which the communicated heat can be carried off by the water; and the maximum of efficiency will be attained when no accumulation of heat takes place in the plates, which must depend entirely on the circulation of the water. There can be no question that horizontal surfaces are the best to absorb heat; bnt unless the heat be carried off by the water, and prevented from accumulating in the plates, the practical value of the surface for generating steam will be much impaired and the plates speedily injured; hence those surfaces are to be preferred, which, combined with naturally good positions for absorbing heat, offer also the greatest facilities for cir. culation of the water. Since, in the case of horizontal surfaces, particularly of large extent, the currents of water tending towards the middle from the outside or from above, can reach the middle only by opposing the ascending currents of steam and water, they must of necessity be more or less diverted from their course; and the circulation being thus interrupted, not only will the gen. eration of steam be less than the surfaces are capable of producing, but as a necessary and more serious consequence, the plates must be subjected to constant over-heating, and sooner or later will become deformed and seriously injured. Under these circumstances an accumulation of deposit usually takes. place, which has been assigned as the cause of the injuries and fractures of the plates, where these have occurred; though in reality the presence of deposit affords evidence only of comparative quiescence or imperfect circulation of the 
water at these parts, of which it is the effect. On this account, therefore, upper horizontal surfaces, especially when of large extent, cannot be the most effective, nor even as effective, as has generally been supposed; indeed, when exposed to the direct action of the fire, they are in many cases objectionable. Surfaces concare towards the fire and heated gases, and flat surfaces deviating somewhat from tho perpendicular, are probably the most effective ; for from these the steam will rise freely, and the water will be brought more readily in contact with the plates, the surface being in a position more favorable for circulation; provided only that the water spaces are not too confined, a fault to be found frequently in locomotive and marine boilers. These remarks will suffice to explain the writer's object in making a distinction in the kinds of heating surface in the boilers experimented upon; and he would express a hope that this important question may be made the subject of further investigation.

There is no doubt that great as has been the progress of late years in the construction of steam engines and the economical use of steam by working expansively, this has not been accompanied by equal progress in the construction of steam boilers; for whatever may be the scientific knowledge in the latter branch of engineering, it certainly is not favarably exhibited in the generality of boilers in present use. On the contrary, the laws of combustion and evapo. ration seem generally to have been almost entirely ignored, and waste of fuel and rapid deterioration of boilers have been the natural consequences. In concluding these remarks, the writer would express a hope that, imperfectly as this subject has been treated, sufficient has been said to show the necessity of further investigation, and to induce other members of the institution to prosecute these inquiries, which cannot fail to prove of great practical value to the manufacturing community.

Mr. B. Goodfellow observed that in making comparative trials of the evapo. rative capabilities of boilers, particular care was requisite to ascertain the quantity of water actually evaporated, free from any loss of water by other causes; as well as to insure exact correspondence in the circumstances of the boilers, not only as to quality of fuel, but also to have the same draught and the same management of the fire. It was very difficult on this account to arrive at the true result; and he had known some double flue boilers that appeared to be giving much less evaporative duty than others, although similar in construction.

The Chairman remarked that the only true comparison of the efficiency of boilers was the measurement of the water actually evaporated with the same fuel; and no correct data could be obtained from the comparison of the indicated horse-power that was often made for the purpose, since in that case the boiler and engine were coupled together, and the effective value of neither of them could be ascertained; for it might be a good boiler coupled to a bad en. gine or the reverse, and the results obtained were unavoidably more or less fallacious from that circumstance. The object to be aimed at was to obtain the form of boiler that best combined the advantages of economy in consumption of fuel with durability, and economy in repairs, and compactness of the space oocupied; the latter points were of great importance in marine boilers and maty cases of stationary engines. 
From Messrs. Eastons and Anderson, of London, England, we have received interesting information relating to their practice of estimating the heating surface of Cornish boilers.

This is to calculate the area of the under side of the shell exposed to heat, the top half of the flues, and six-tenths of the total area of the tubes; and allow twelve feet of such heating surface to evaporate a cubic foot of water from 62 to $212^{\circ}$; this would require 10.4 square feet to evaporate the same from and at $212^{\circ}$-or more if the total tube surface were estimated.

An example is given by them of an experiment with a double flue Cornish multitubular boiler $6^{\prime} .6^{\prime \prime}$ dia., 20 feet $1 \frac{1}{2}$ in. long, with two flues $2^{\prime} \cdot 6^{\prime \prime} \times 14^{\prime} \cdot 6 u^{\prime \prime}$ long. Number of tubes in each flue $37 ; 3^{\prime \prime}$ diam., 5'.71" long. Length of grate six feet. The boiler was fired internally, the gases passing through the flues and tubes, and return. ing on each side to the front end, and back again under the centre to the chimney at the rear.

Heating surface of boiler-

Shell exposed to heat, . . . 210 sq. feet.

Flue " " . . . . . 165 " 6

Tube surface $310 \mathrm{sq} . \mathrm{ft} . \times{ }_{10}^{6}, \quad$. $\quad 186$ " $\quad$ "

$561 \mathrm{sq}$. feet.

Evaporation per hour from and at $212^{\circ}, 53^{\prime} .6$ cubic feet.

Actual water evaporated per $\mathrm{th}$ of coal from $101^{\circ}$ to $212^{\circ}, 8.78$; from and at $212^{\circ}, 9.8$, estimated. Coal burnt per sq. foot of grate $11.2 \mathrm{mb}$.

Coals, light burning Newcastle. Height of chimney above fire 95 feet. Feed water heated to $101^{\circ}$ by exhaust steam from Donkey pump.

Pressure of steam 40 to 46 lbs. Temperature of gases in smoke box at the end of $3^{\prime \prime}$ tubes $950^{\circ}$; at the end of flues $670^{\circ}$ Fah.

$561 \div 53.6$ equals $10.5 \mathrm{sq}$. feet, nearly, of heating surface to evaporate a cubic foot per hour from and at $212^{\circ}$, with an economy of 9.8 lbs. water evaporated per lb. of coal.

Estimated amount required to evaporate a cubic foot of water per hour from and at $212^{\circ}$, based on an economy of $9 \mathrm{lbs}$. of water per lb. of coal, (as per preliminary report of the committee,) $9.5 \mathrm{sq}$. feet.

If, instead of six-tenths of the tube surface we calculate the total tube surface as effective, we should require 11.7 instead of $9.5 \mathrm{sq}$. ft.

We have also received from the same firm the report of the Royal 
Agricultural Society, to which they are Consulting Engineers, and from which report we make interesting extracts relating to the trials of Traction Engines, at Wolverhampton, in 1871.

The following is a general description of the Boilers tried:

No. 1. Aveling and Porter's Locomotive Boiler, 53 tubes $2 \frac{1}{2}$ external diam. Collective area $169 \frac{1}{2}$ feet, which, with the fire-box, makes a total of $204 \frac{3}{8}$.

No. 2. Locomotive Boiler by the same maker; containing 28 tubes, $2 \frac{1}{2}$ inches outside diam.

No. 3, By the same maker, is precisely similar to No. 2 .

No. 4. Locomotive Engine with $332 \frac{1}{4}$ inch (outside diam.) tubes, by Charles Burrell.

No. 5. Tuxford and Sons, Locomotive Boiler. Heating surface of fire-box, $21.41 \mathrm{sq}$. feet; surface of tubes, 132.75 feet.

No. 6. Howard's Safety Boiler. This boiler is of the horizontal water-tube type; the interior tubes being 9 inches in diam; the sidetubes, which touch each other, are 6 inches in diam. The ends are connected with upright $D$-shaped tubes. Total heating surface, taking only, as regards the two outside rows of tubes, their semi-circumference towards the fire, 276 feet; of which, probably, 184 may be taken as boiling surface, and 92 feet as super-heating surface.

No. 7. By Ranson, Sims and Head, is called a "Pot Boiler." We will briefly describe it. It consists of a plain vertical cylinder, containing at its lower end an internal cyljnder of lesser diameter, forming the fire-box; there is a circular opening about $1 \mathrm{ft} .1 \frac{1}{2}$ in. diameter, to which is jointed the neck of the copper pot. Below the neck the pot swells out into a spherical form, and is of such a size as nearly to fill the fire-box; leaving, however, a space of about $1 \frac{1}{2}$ inch all round between itself and the inside of the fire-box. Up this space the products of combustion pass; and they make their escape from the fire.box through 36 vertical tubes, $1 \frac{7}{8}$ inch bore, 3 feet $10 \frac{1}{2}$ inches in length, which are inserted in the crown plate of the fire-box in the space left between its sides and the neck of the pot. The grate area is 5.25 square feet. Heating surface up to the water line 80.5 feet. Super-heating surface 46 feet. Total, 126.5.

No. 8. Pot Boiler by Chas. Burrell. Heating surface up to water line, 85.5 feet. Super-heating surface, 35.2 feet.

In the table annexed, referring to the performance of these boilers, we conclude that the total area of the tube surface was reckoned. We 
have here based the evaporative duty of the boilers at $8 \mathrm{lbs}$. of water, instead of 9 , as in the use to which these boilers were applied, that of traction engines, it is of as much importance to have a light engine as a very economical one.

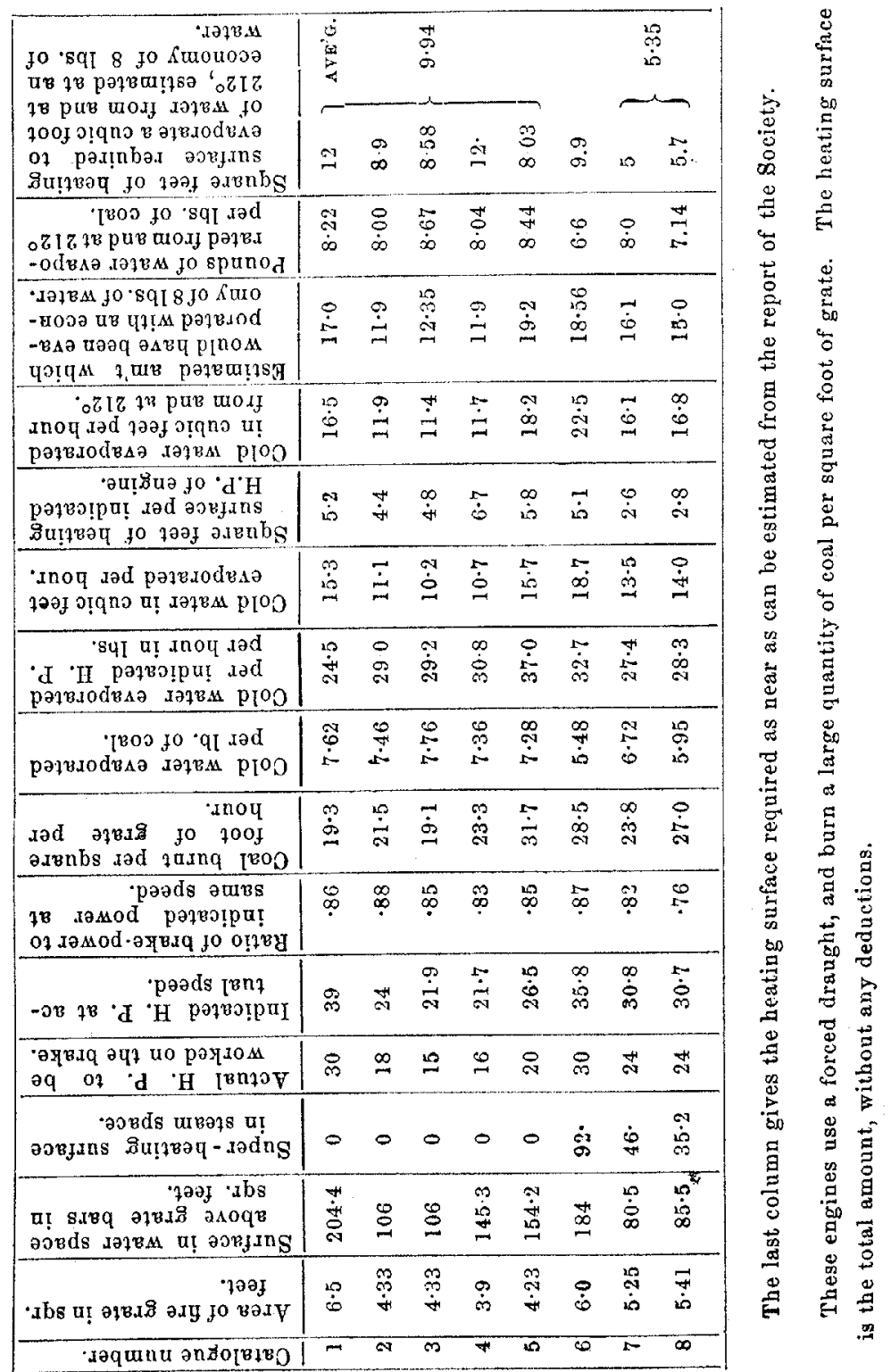




\section{Marine Boilers.}

We extract from Isherwood's Engineering Precedents as follows: "Experiments on eight different Marine Boilers to determine the evap. orative efficiency."

\begin{tabular}{|c|c|c|c|c|c|}
\hline Name of Steamer. & Description of Boiler. & 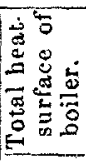 & 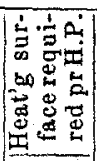 & 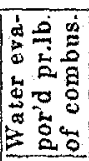 & 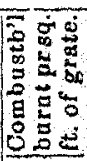 \\
\hline Jacob Bell,... & Hor. Tubes \& Flues,..... & 1484 & 19 & 12 & 11 \\
\hline Mount Vernon, & 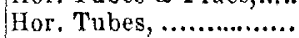 & 2374 & 19 & 10.5 & 105 \\
\hline Valley City, .................... & Hor. Tubes, .................. & 953 & 16 & $11 \cdot 2$ & $9 \cdot 16$ \\
\hline 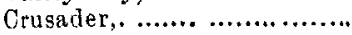 & Hor. Tubes, ................... & 1056 & 16.8 & 118 & $9 \cdot 3$ \\
\hline 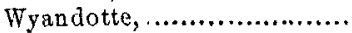 & Martin Vert. W. Tubes,.. & 1993 & 20 & 12.4 & 10 \\
\hline 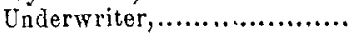 & Hor. Flue, $12^{\prime \prime} \& 20^{\prime \prime}, .$. & 1817. & $15 \cdot 6$ & $11 \cdot 2$ & $9 \cdot 9$ \\
\hline Young America,................ & Hor. $6^{\prime \prime}$ Tubes, ........... & 981 & 15 & 10.4 & $9 \cdot 3$ \\
\hline \multirow[t]{2}{*}{ Boiler of N. Y. Navy Yard,.. } & Hor. Tubes, ................ & 1143 & 18 & $11 \cdot 1$ & $11 \cdot 5$ \\
\hline & & & $139 \cdot 4$ & $90 \cdot 6$ & 80.6 \\
\hline Average,......... & $\ldots \ldots \ldots \ldots \ldots$ & & 17.4 & $11 \cdot 3$ & $10 \cdot 0$ \\
\hline
\end{tabular}

In these trials the boilers were not pushed to the full capacity on an evaporation of nine lbs. of water, or we should find that less heating surface would have been required.

From the same source we also extract as follows :

Experiments with vertical water tube boiler and natural draft.

\begin{tabular}{|c|c|c|c|c|}
\hline Name of Steamer. & $\begin{array}{l}\text { Total Heating } \\
\text { surface of } \\
\text { boiler. }\end{array}$ & $\begin{array}{l}\text { Heating surface } \\
\text { required } \\
\text { H.P. per }\end{array}$ & $\begin{array}{l}\text { Water evapor- } \\
\text { ated pr.lb.of } \\
\text { combustible. }\end{array}$ & $\begin{array}{l}\text { Comb. burnt } \\
\text { per sqr. foot } \\
\text { of grate. }\end{array}$ \\
\hline \multirow[t]{2}{*}{ San Jacinto, } & 3295 & $18 \mathrm{ft}$ & $12 \cdot 6$ & $9 \cdot 9$ \\
\hline & \multicolumn{4}{|c|}{ The same with forced draft. } \\
\hline “ & 3295 & $10 \mathrm{ft}$. & $8 \cdot 67$ & $19 \cdot 8$ \\
\hline \multicolumn{5}{|c|}{ Horizontal fire tube boiler, natural draft. } \\
\hline Name of Steamer. & $\begin{array}{c}\text { Total feating } \\
\text { surface of } \\
\text { boiler. }\end{array}$ & $\begin{array}{l}\text { Heating surface } \\
\text { required per } \\
\text { H. P. }\end{array}$ & $\begin{array}{l}\text { Water evapor- } \\
\text { ated pr.lb.or } \\
\text { combustible }\end{array}$ & $\begin{array}{l}\text { Comb. burnt } \\
\text { per sqr, foot } \\
\text { of grate. }\end{array}$ \\
\hline \multirow[t]{2}{*}{ San Jacinto, } & 2663 & $16 \mathrm{ft}$. & $10 \cdot 3$ & 10.7 \\
\hline & \multicolumn{4}{|c|}{ The same with forced draft. } \\
\hline 6 & .2663 & $10 \mathrm{ft}$. & 8. & 20 \\
\hline
\end{tabular}

From the above it appears that the heating surface required to evaporate one cubic foot of water from and at $212^{\circ}$ (economy $9 \mathrm{lbs}$ of 
water) ranges between 12 and 14 feet, calculating all the $H$ S. as effective.

The present practice of the U.S. Navy is to allow $8 \mathrm{lbs}$. of anthracite coal per hour to evaporate one cubic foot of water at $100^{\circ}$ into dry steam, under a pressure of 30 lbs. above the atmosphere, which requires $\frac{2}{3}$ square foot of grate, $16 \frac{2}{3}$ square feet of heating surface, and one-twelfth square foot calormeter.

\section{Sectional and other Boilers tested at the Fair of the American Insti- tute, New York, 1871.}

The report of this trial having appeared in full in a previous num. ber of the Journal, we shall only extract the most important portion.

The boilers tested were as follows:

The Root.-This boiler consists essentially of 80 wrought-iron tubes 4 inches diameter and 9 feet long. These tubes are set in brick work at an angle of about $30^{\circ}$ from the horizontal.

The tubes are connected together at the ends by a system of triangular plates and crowfeet. The boiler has a steam drum 18 inches by $6 \frac{3}{4}$ feet long. The superheating is effected in the upper portion of the boiler.

In calculating the heating surface of these boilers, the total area exposed to contact with combustion is taken as heating surface.

The Allen Boiler.-In this boiler the roof of the fire chamber is made of nine cast-iron cylinders, each 7 inches internal diameter and 11 feet long; and into each of these cylinders 18 wrought-iron tubes, $3 \frac{1}{2}$ inches in diameter, are screwed, the lower ends being closed by plugs. These tubes hang down from the roof into the fire chamber, and are set at an angle of about $20^{\circ}$ from the vertical; the lower end being furthest from the fire door. The tubes over the fire are 3 feet two inches long, the rear ones are 4 feet 5 inches long. Steam drums are arranged over the boiler.

The Phleger Boiler.-This consists of a number of wrought-iron tubes, nearly horizontal, connected to wrought iron tube plates and set in brick-work. There are 17 bent tubes, 2 inches in diameter and 15 feet long, so arranged as to form the furnace and water grate, being secured at the ends to wroughtiron tube sheets. There are also 68 straight tubes of the same dimensions, secured at the ends to wrought tube sheets. These tubes are all connected with each other and the steam drum, which is $2 \frac{1}{2}$ feet diameter and 12 feet long, and which contains shelves or the prevention of foaming. 
The Lowe Boiler. - This is a horizontal tubular boiler, with the firo under one end. The products of combustion pass within the boiler to a combustion chamber, then through the tubes and around the under side of the shell of the boiler. In the trial, two boilers placed side by side were tested. 'The larger boiler was 4 feet diameter, 15 feet 4 inches long, and contained 45 tubes 3 inches in diameter and 12 feet long.

The other boiler was of the same length as the first, but only $3 \frac{1}{2}$ feet in diameter, and contained 36 tubes 3 inches in diameter.

The Blanchard Boiler.-This boiler has a fire-box similar to a locomotive, and the fire-tubes, instead of being horizontal, are vertical, and at the rear end of the fire-box. These tubes are 94 in number, and $4 \frac{1}{2}$ feet long by 2 inches in diameter. A superheater is above these tubes, but it was not used in the trial.

In the test of these boilers we have the first attempt to estimate the true evaporation. This was done by condensing all the steam made by passing it into a tank in which was a condensing pipe having 1100 square feet of surface. The temperature of the water of condensation, as also that of the condensing water, being constantly noted as it escaped, the amount of water evaporated into steam could be calculated therefrom. There are other less expensive methods than the above described, by which the true amount of water evaporated may be arrived at sufficiently near for practical purposes.

The table which follows shows the result of the trial.

The trial above recorded shows what amount of water can be evaporated per pound of combustible, rather than the heating surface required in the usual conditions of use. We cannot, from the figures here given, even approximate to the heating surface required at an evaporation of 9 pounds of water. Estimating the power of a boiler by the heating surface, as is common with boiler makers, we conclude that the Allen boiler shows the greatest economy, having evaporated 10.60 pounds of water per pound of combustible, with 17.41 feet of heating suriace, the other boilers requiring 22 feet and over. It is evident that considerably less than 17 feet will answer per horse power on this boiler, when new, but how much less the experiment does not show.

To make a trial like this thoroughly practical in its utility, we should have the tests made at two or three different rates of evaporation within the limits at which the boiler is likely to work. The pur- 


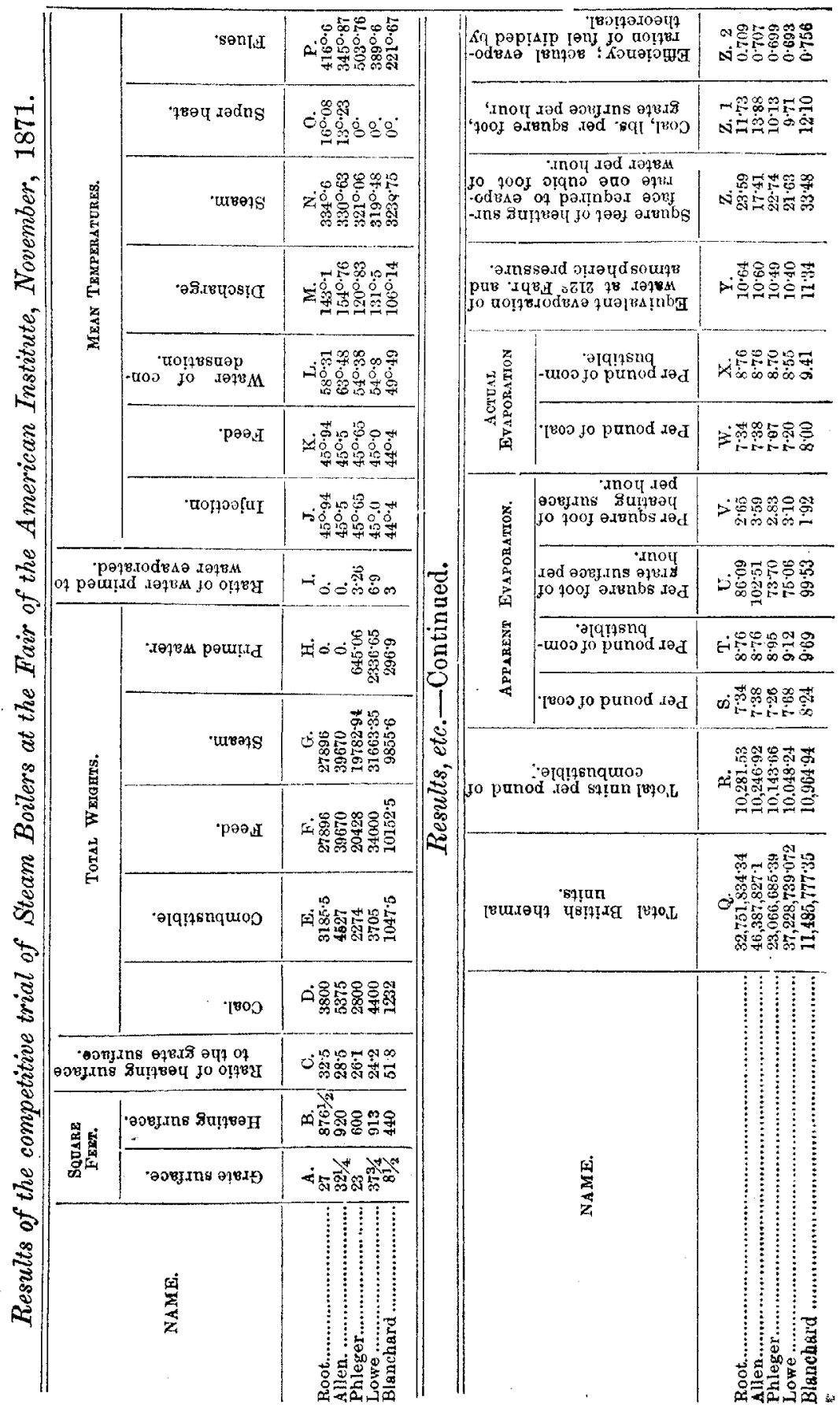


chaser could then choose the boiler, and the amount of heating surface corresponding to the economy desired.

It is very important that all trials, to be of practical use, should be made as near as possible under the same conditions at which the boiler is intended to work in actual commercial use.

\section{MUititubular BoIler.}

We have received from Mr. H. S. Robinson, Engineer at the Pacific Mills, Lawrence, Mass., the results of a careful trial of a steamboiler at those works, the trial ending July 19, 1871.

The boiler is cylindrical and horizontal, 21 feet long and 5 feet diameter, having 58 tubes, $3 \frac{7}{2}$ " diameter 20 feet long, set square, 1 inch apart and 3 inches from the shell. Smoke-box, 12 inches, projecting into the fire-room. The boiler is fired externally, the gas passing under the bottom and back through the tubes. The trial lasted 49 hours ; average pressure of steam, $49 \mathrm{lbs}$; steam apparently dry.

There is no superheating. Grates, $5^{\prime} 2^{\prime \prime}$ long. "

\begin{tabular}{|c|c|c|c|c|c|c|c|c|c|}
\hline \multicolumn{3}{|c|}{ Heating Surface of Boiler. } & \multirow[b]{2}{*}{ 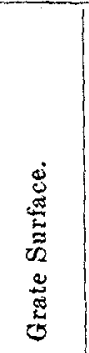 } & \multirow[b]{2}{*}{ 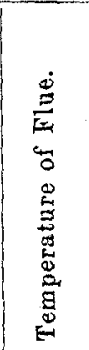 } & \multirow{2}{*}{ 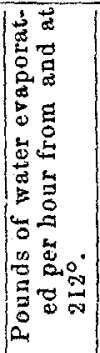 } & \multirow{2}{*}{ 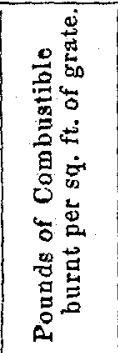 } & \multirow{2}{*}{ 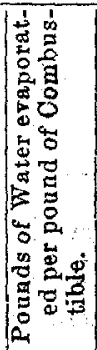 } & \multirow{2}{*}{ 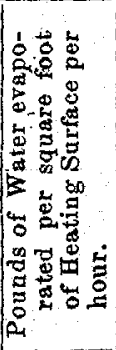 } & \multirow{2}{*}{ 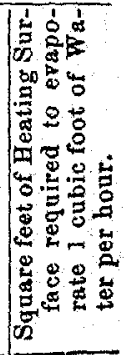 } \\
\hline 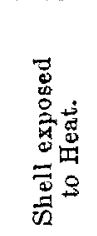 & 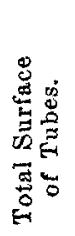 & Total. & & & & & & & \\
\hline 140 & 1063 & $\begin{array}{l}\text { Fir } \\
1203 \\
\text { With } \\
1203\end{array}$ & $\begin{array}{c}\text { st Tria } \\
25.8 \\
\text { Hamps } \\
25.8\end{array}$ & $\begin{array}{r}1 \text { with } \\
332^{\circ} \\
\text { hire \& }\end{array}$ & $\begin{array}{l}\text { Anthr } \\
2883 \\
\text { Baltim } \\
3090\end{array}$ & $\begin{array}{c}\text { acite Co } \\
9.5 \\
\text { ore } \mathrm{Co} .{ }^{\prime} \mathrm{s} \\
9.5\end{array}$ & $\begin{array}{l}\text { al. } \\
11 \cdot 7 \\
\text { Soft } \\
12 \cdot 63\end{array}$ & $\begin{array}{c}2.396 \\
\text { Coal. } \\
2.568\end{array}$ & 23 \\
\hline
\end{tabular}

In examining this report, we note the low temperature of the escaping gases, the small quantity of coal burnt per sq. foot of grate, the great economy in the water evaporated, and the large heating surface required.

The bituminous coal evaporated the most water.

The rate of economy is so much above the average, that we could not even approximate from this trial what heating surface would bo required at an economy of 9 lbs. of water. 
Mr. Robinson has also furnished us with a trial of a Harrison castiron boiler, made at about the same time and with the same coal.

This boiler was in the same shed as the multitubular boiler, and was set according to the usual plan of the maker. The boiler itself is too well known by the public to need any particular description. This one consisted of 8 slabs, the superficies of which is estimated at 90 feet each, making a total of $720 \mathrm{sq}$. feet of heating surface.

\begin{tabular}{|c|c|c|c|c|c|c|c|}
\hline 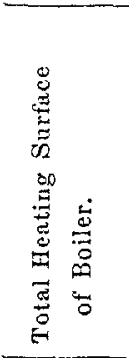 & 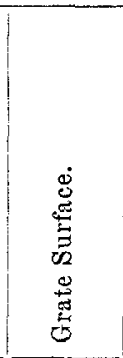 & 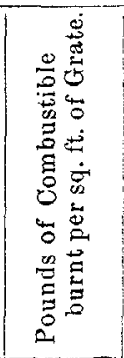 & 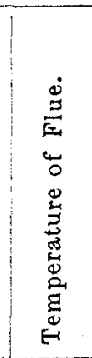 & 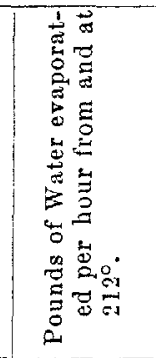 & 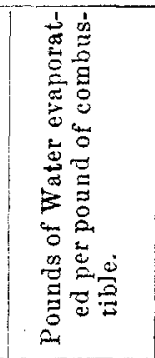 & 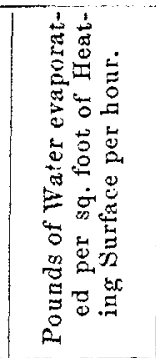 & 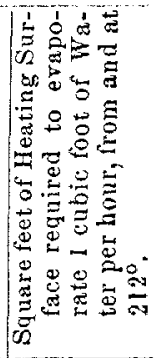 \\
\hline irst Tria & $1 \mathrm{wi}$ & nth & Coal, & lasting 48 & hours, endi & ng $6 \frac{1}{2}$ A.M & , Jul \\
\hline 720 & $\begin{array}{r}2 \\
\text { Firs }\end{array}$ & $\begin{array}{r}9 \cdot 7 \\
\text { al with }\end{array}$ & $\mathrm{itt}$ & 2251 & $\begin{array}{r}9.4 \\
\text { nding }\end{array}$ & 29. & \\
\hline $\begin{array}{l}720 \\
\text { Sec }\end{array}$ & $\begin{array}{c}24.37 \\
\text { ond Tria }\end{array}$ & $\begin{array}{c}8 \cdot 7 \\
1 \text { with } A\end{array}$ & & ite Coal, en & $\begin{array}{c}9.74 \\
\operatorname{ding} 61\end{array}$ & $\begin{array}{c}2 \cdot 868 \\
\text { Mr., July } 22\end{array}$ & $\begin{array}{r}2 \\
187\end{array}$ \\
\hline $720^{\circ}$ & & $\begin{array}{l}4 \cdot 6 \\
\text { Secon }\end{array}$ & $\begin{array}{c}427 \\
\text { d Tria }\end{array}$ & $\begin{array}{c}1227 \\
1 \text { witb Bitu }\end{array}$ & $\begin{array}{c}10.84 \\
\text { minous Co }\end{array}$ & al. 1.704 & \\
\hline 720 & $24: 37$ & $5 \cdot 4$ & & & & 923 & 809 \\
\hline
\end{tabular}

It will be observed that in this trial, as also in the previous one of the multitubular boiler, and the sectional boilers in New York, that the evaporative economy is much above $9 \mathrm{lbs}$. of water per lb. of coal, requiring a larger amount of heating surface than would usually be given per horse-power by the maker.

\section{ReCAPITULATION.}

With the limited number of accurate experiments available upon which to base the heating surface required on various boilers to evap. orate a cubic foot of water per hour from and at $212^{\circ}$, and recogniz. ing fully the various causes modifying the heating surface required, as given in the preliminary report, your Committee can only give an approximate estimate, based upon the preceding tables of trials, and under the conditions therein stated. 
From the Report of $R$. B. Longridge.

Plain Cylinder Boiler with Flues, reckoning surface exposed Feet. above heat only, or against which the current strikes, economy 9 lbs.,

Galloway and Galloway Multitubular, . . . $\quad 8.5$ Multitubular, Figure 14, . $\quad$. $\quad$. $\quad \cdots \quad \cdots 5$ " " calculating the total surface of the tubes,

The following are calculated at the total heating surface:

From 1sherwood's Engineering Precedents.

Marine Boiler, horizontal tubes, - 14 .

From Report of Messrs. Eastons \& Anderson.

Double-Flue Cornish Multitubular, nearly similar to Figure 14, 11.7

From Report of the Royal Agriculture Society, England. Portable Engines, forced draft, economy 8 lbs. of water.

Locomotive Boiler, . 10 .

Howard's Section Water Tubular, . . . 10. Pot Boiler, - 5.35

In estimating the heating surface required to evaporate a cubic foot of water in similar boilers, a small addition must be made to the above figures, depending upon the temperature of the feed entering the boiler, and pressure of steam.

In conclusion, your Committee return thanks to those Engineers who have favored them with their opinions, or assisted in furnishing materials for this report.

EDWARD BROWN, JOHN H. COOPER, W. Barnet Le VAN, WiLLTaM H. WaHL.

Hall of the Institute, June 18, 1872.

After the reading of the paper it was, upon motion, resolved that the thanks of the Institute be presented to the Committee for the labor and time bestowed in preparing their valuable report, and that the Ootober meeting of the Institute be fixed as the time appointed for discussing the report. 